\title{
Association between Opuntia species invasion and changes in land-cover in the Mediterranean region
}

\author{
MONTSERRAT VILÀ*, JOSÉ ANGEL BURRIEL*, JOAN PINO*, JOAN CHAMIZO†, \\ EMMA LLACH†, MONTSERRAT PORTERIAS † and MIQUEL VIVES † \\ ${ }^{*}$ Center for Ecological Research and Forestry Applications and, Universitat Autònoma de Barcelona, 08193 Bellaterra, Barcelona, \\ Catalonia, Spain, †Departament de Ciències Ambientals, Universitat de Girona, E-17071 Girona, Catalonia, Spain
}

\begin{abstract}
In Mediterranean regions, biological invasions pose a major threat to the conservation of native species and the integrity of ecosystems. In addition, changes in land-cover are a widespread phenomenon in Mediterranean regions, where an increase in urban areas and major changes from agricultural abandonment to shrub encroachment and afforestation are occurring. However, the link between biological invasions and changes in land-cover has scarcely been analyzed. We conducted a regional survey of the distribution of the two alien prickly-pear cacti Opuntia maxima and O. stricta in Cap de Creus (Catalonia, Spain) and related patterns of invasion to spatially explicit data on land-cover/change from 1973 to 1993 to test the hypotheses that the two Opuntia species invade areas that have experienced large land-cover transformations. We found that Opuntia invasion is particularly high in shrublands and woodlands located near urban areas. $O$. maxima are over-represented in the shrublands and $O$. stricta in the woodlands that were former crops. Crop coverage has dropped by $71 \%$ in this 20 -year period. This study highlights the role of past land-cover in understanding the present distribution of plant invasions.
\end{abstract}

Keywords: alien species, Cactaceae, GIS, land transformation, Mediterranean vegetation, old olive groves, Opuntia maxima, Opuntia stricta, prickly-pear cacti

Received 3 December 2002; revised version received and accepted 18 March 2003

\section{Introduction}

Biological invasions and changes in land-cover are two of the most prominent components of global change (Vitousek, 1994). Some changes in land-cover are usually associated to landscape disturbances that represent open windows to the invasion of alien species (Hobbs, 2000). For example, ruderal and man-modified ecosystems such as human settlements, oldfields, roadsides and areas near croplands are ecosystems with a high number of alien species or where specific alien plants become abundant compared to more natural ecosystems (Kowarik, 1990; Tyser \& Worley, 1992; Bountin \& Jobin, 1998; Pysek, 1998). However, despite the presumption that changes in land-cover are one of the major forces driving invasion at the landscape scale (Hobbs, 2000), there is scarce research

Correspondence: Montserrat Vilà, tel. 93-5813345, fax 93-5811312, e-mail: montse.vila@uab.es on the link between both phenomena in a spatiotemporally explicit way (Thomson et al., 1993).

It has been predicted that Mediterranean regions will experience an increased intensity in the abundance and impact of biological invasions (Sala et al., 2000). Moreover, although the Mediterranean Basin has experienced major human-driven changes over the last 10000 years, changes in land-cover due to an increase of urban areas in coastal regions and also due to agricultural land abandonment are currently occurring at even faster rates than in the past and in a more irreversible way (Debussche et al., 1999). These changes will be intensified in the coming decades (Sala et al., 2000). Therefore, this region is an appropriate study system to investigate the links between plant invasions and changes in land-cover.

Prickly-pear cacti (Opuntia spp.) are one of the most well-known examples of a plant genus that has invaded different habitats around the world (Cronk \& Fuller, 1995). Opuntia are stress tolerant (e.g. salinity, drought), succulent CAM plants with a highly efficient water use 
(Gersani et al., 1993; Luo \& Nobel, 1993). Furthermore, its life form, which is different from any Mediterranean Basin native species, could well explain their success in invading Mediterranean and semiarid areas (Cortázar $\&$ Nobel, 1990). The objective of this study is to describe the distribution of Opuntia maxima and O. stricta in a Mediterranean landscape in relation to land-cover change. Our hypothesis is that the distribution of Opuntia is not random and it invades areas that have experienced large land transformations.

\section{Material and methods}

\section{Study species}

Opuntia spp. (Cactaceae) are noncolumnar cacti ('nopales') introduced from Central America to Europe by the Spanish conquerors between the end of the 15th century and the beginning of the 16th century (Barbera et al., 1992). In Europe, Opuntia spp. have been used for fruit consumption, livestock foraging, fencing, as ornamentals and for the production of a red dye that was obtained from the infesting cochineal insect Dactylopius coccus (Ellenberg, 1989; Inglese et al., 1995). The two study species were Opuntia maxima that present an average height of $3 \mathrm{~m}$ and $O$. stricta that does not attain more than one meter height (Castroviejo et al., 1990). Vegetative reproduction is common. Cladodes break off and root, usually near the parental ramet and form conspicuous patches. However, in the study area seedling recruitment far from maternal plants is also important (Gimeno \& Vilà, 2002).

\section{Study site}

The study site was located at the Natural Park of Cap de Creus i Serra de la Verdera (Catalonia), a 13575 ha protected coastal area located in Catalonia, northeast Spain. Like other European Mediterranean regions, during the last few decades this area has experienced great changes due to tourism, an increment in disturbances (fire frequency, housing development), crop abandonment and a concentration of tourist resorts in coastal areas (Folch, 1988). The climate is Mediterranean with cool, wet winters and warm dry summers. Mean monthly temperatures of the coldest (January) and hottest (August) months are $4{ }^{\circ} \mathrm{C}$ and $31{ }^{\circ} \mathrm{C}$, respectively. The mean annual precipitation is $600 \mathrm{~mm}$. The soils are acidic loamy sands (Vilà, 1996). The vegetation is mainly dominated by old terraced abandoned olive groves and vineyards, colonized by sclerophilous shrublands and afforested pine woodlands (Franquesa, 1989).

\section{Field survey of sites invaded by Opuntia}

Current Opuntia maxima and O. stricta distribution was assessed by an extensive field survey during which the presence of Opuntia was recorded on a 1:10000 scale map by sight and with the help of binoculars. The survey was conducted by driving and walking on all roads and pathways of the Natural Park. The large extension of the communication network and the sloping landscape of the Natural Park allowed the Opuntia to be easily visible from a distance. Furthermore, because Opuntia contrasts greatly with the Mediterranean vegetation, we are confident that the presence and distribution of these species was correctly determined. For each area invaded by Opuntia and detected in the field survey, the following land-cover types were assigned: denuded (mostly rocky), pine woodland, shrubland, old olive grove, coastal, urbanruderal and grasslands. Invaded areas delimited on the paper orthophotomaps were digitalized and georeferenced with MiraMon, an in-house developed GIS (Pons, 2001).

\section{Mapping land-cover/change}

Field information on the habitat type invaded by Opuntia was complemented by a GIS approach aimed at comparing recent land-cover changes in the whole Cap de Creus peninsula and the areas invaded by the species. The current landscape has been assessed from the Land-Cover Map of Catalonia (LCMC) (http:// www.uab.creaf.es/mcsc) conducted at the Center for Ecological Research and Forestry Applications (CREAF), a digital product that includes recent (1993) basic land-covers of forestry interest (grassland, shrubland and woodland) and other complementary covers (rocky outcrops, waterbodies, denuded areas, crops and urban areas) in Catalonia. Area delimitations of the cover types were determined by photo-interpretation and on-screen digitizing, using digital 1:25000 orthophotomaps as support. A vectorial polygon was obtained, which was finally converted into raster format; with a pixel size of $5 \mathrm{~m}$. MiraMon has been used throughout the process of cartography (Pons, 2001).

A previous land-cover map had been derived from the Map of Crops and Exploitation of Spain (MCE) corresponding to Catalonia, generated by the Ministry of Agriculture (Directorate General for Agricultural Production) in 1973 (http:/ / www.gencat.es/mediamb/ sig/fmca.htm). It is a cartographic series of paper maps on a scale of 1:50000 based on a topographic 1:50000 series of Spain. Maps were generated by fieldwork carried out in the early 1970s, and contain information 
similar to the LCMC, including basic covers of agricultural interest and other complementary covers such as nonproductive areas (corresponding to denuded and rocky categories in the LCMC), but it does not have information on urban land-cover. Paper maps were scanned and georeferenced with a maximum permitted error (RMS) of $10 \mathrm{~m}$ in the Department of Geography (Universitat Autònoma de Barcelona). After georeferencing, maps were on-screen digitized similar to the LCMC, and final polygon maps were rasterized to a $5 \mathrm{~m}$ pixel size. Georeferencing, digitizing and raster generation were performed using MiraMon.

Land-cover changes in nonurban categories from 1973 to 1993 have been evaluated by crossing the rasters of the LCMC and the MCE using MiraMon. Cover changes in woodlands, shrublands, grasslands, crops and nonproductive areas (rocky and denuded) have been analyzed separately for the entire Cap de Creus region and the particular areas occupied by Opuntia maxima and $O$. stricta.

To test statistically as to whether the Opuntia invasion-land-cover/change association was not biased towards the most abundant land-cover/changes, we compared if the observed Opuntia area of distribution within the land-cover/changes in the area of study (observed value) was significantly different from the relative frequency of these land-cover/changes (expected value) by $X^{2}$ goodness-of-fit analysis. We also tested if there was a relationship between the area of the invaded patches and the distance from urban areas by the Spearman rank correlation test. The distance between the invaded areas and the urban areas was calculated by crossing the digitalized invaded maps with the LCMC using MiraMon, and calculating the length between the centroid of each invaded area and the periphery of the closest urban area.

\section{Results and discussion}

O. maxima were found in 98 sites and O. stricta were found in 34 sites. Both species coexisted in 11 sites. In total, O. maxima extended over 278.50 ha $(2.26 \%)$ and $O$. stricta extended over 97.87 ha $(0.79 \%)$ of the study site. Invaded areas ranged from 956 to $290994 \mathrm{~m}^{2}$ for $O$. maxima and from 837 to $291021 \mathrm{~m}^{2}$ for O. stricta. Although for O. maxima most invaded areas were small and $O$. stricta had a more even distribution, the mean $( \pm \mathrm{SE})$ area was not significantly different between species $\left(t\right.$-value $=0.03, P=0.97 ; 28478.53 \pm 5392.77 \mathrm{~m}^{2}$ for O. maxima and $28778.72 \pm 8604.09 \mathrm{~m}^{2}$ for O. stricta).

According to the GIS analysis, most land in Cap de Creus is nowadays occupied by shrublands (69.79\%) followed by woodlands (15.30\%). By contrast, in the 1970s, although shrublands and woodlands were also abundant (31.58\% and $11.15 \%$, respectively), most land was occupied by grasslands (43.75\%), a land-cover that now only occupies $2.42 \%$ of the area. The distribution area of crops was $13.51 \%$, but now it represents less than $6 \%$. The most invaded land-covers are shrublands followed by woodlands (Fig. 1). The analysis of the association between Opuntia invasion and land-cover demonstrates that this distribution is not random. The observed invasion distribution is significantly different from the expected $\left(\chi^{2}\right.$ test $=93182.27, \mathrm{df}=5, P<0.0001$ for O. maxima and $\chi^{2}$ test $=35107.34, \mathrm{df}=5, P<0.0001$ for O. stricta). O. maxima invasion is over-represented in shrublands $(81.34 \%)$ and under-represented in the other habitats, except for crops for which observed values are not significantly different from the expected. O. stricta is over-represented in woodlands $(26.42 \%)$ and grasslands $(3.71 \%)$.

Cap de Creus has experienced a major land-cover change from 1973 to 1993 (Table 1). On average, landcover changes have occurred in (mean $\pm \mathrm{SE}$ ) $70.32 \pm 11.33 \%$ of the area. For example, $53.74 \%$ of the land occupied by crops, $68.86 \%$ of the grasslands and $71.43 \%$ of the woodlands changed to shrublands. Already existing shrublands in 1973 are the land-cover that has changed the least $(28.09 \%)$ in this 20-year period.

Our analysis confirms that Opuntia is invading habitats that have experienced major changes in this 20-year period. O. maxima mostly invade shrublands that were formerly crops in 1973 . The distribution of $O$. maxima in shrublands that were formerly crops is larger than expected $\left(\chi^{2}\right.$ test $\left.=677968.2, \mathrm{df}=5, P<0.0001\right)$. Similarly, O. stricta is over-represented in woodlands thatwere crops in $1973 \quad\left(\chi^{2}\right.$ test $=45688, \quad d f=5$, $P<0.0001$ ) (Fig. 1).

Our field survey was consistent with the GIS analysis. It revealed that a great number of shrublands invaded by O. maxima were old olive groves $(29.32 \%)$. Concomitantly, $36.33 \%$ of areas invaded by $O$. stricta corresponded to afforested Pinus pinea woodlands. Abandoned olive groves and pine woodlands are probably more invaded than other habitats because of seed disperser birds (e.g. Turdus philomelos and Sturnus vulgaris) that have consumed fruits perch on these trees (Vilà \& Gimeno, 2001), beneath which cacti are more protected from environmental stress than in the open. Therefore, trees act as nurse plants for the growing cactus (Valiente-Banuet \& Ezcurra, 1991; Cody, 1993).

The majority of invaded areas are located less than $200 \mathrm{~m}$ from urban settlements (Fig. 2). The areas invaded by $O$. maxima that are close to urban zones were significantly larger than the ones far from urban areas (Spearman's correlation coefficient $r=0.21$, $P=0.03$ ), but the relationship was not significant for 

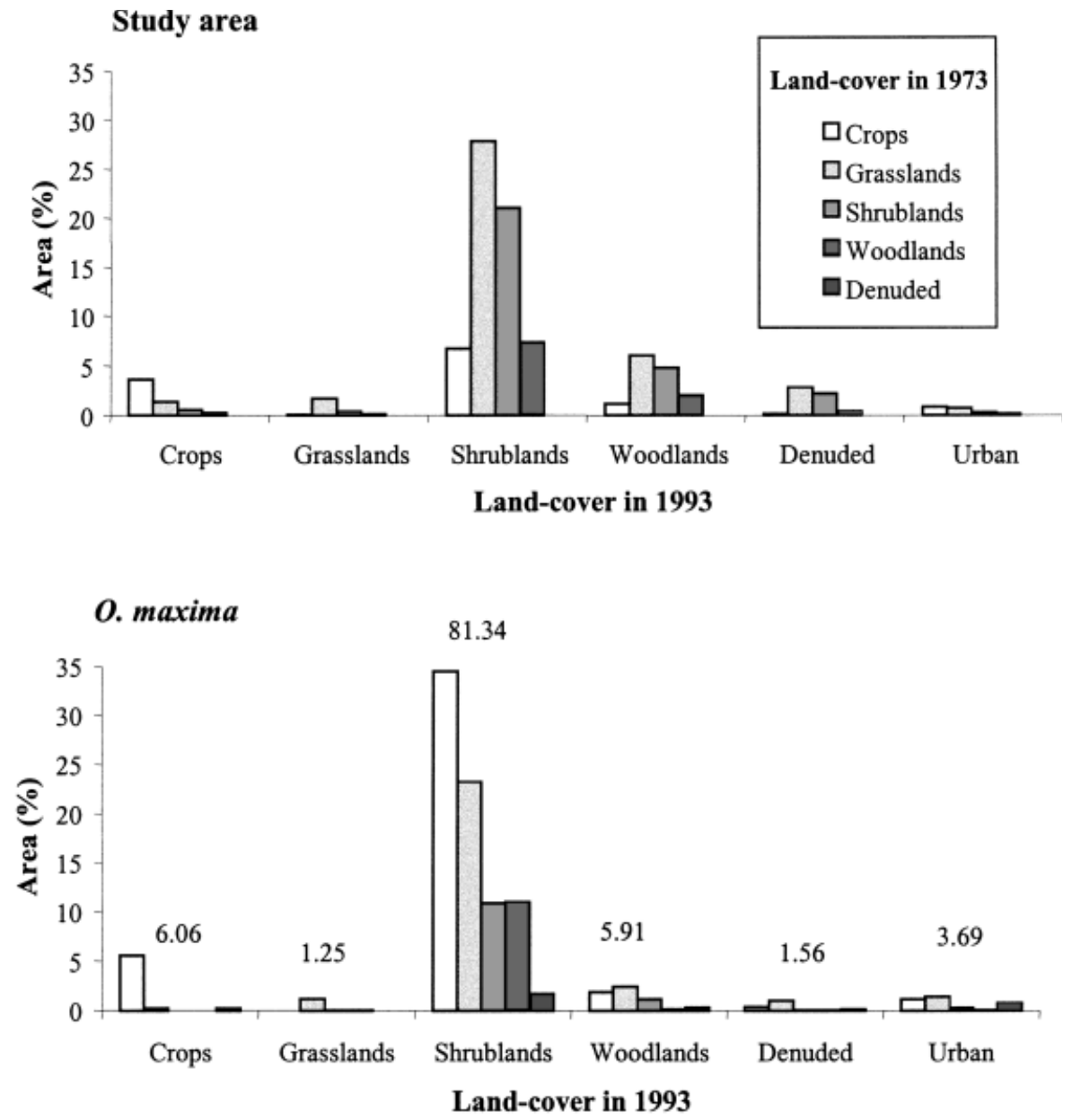

O. stricta

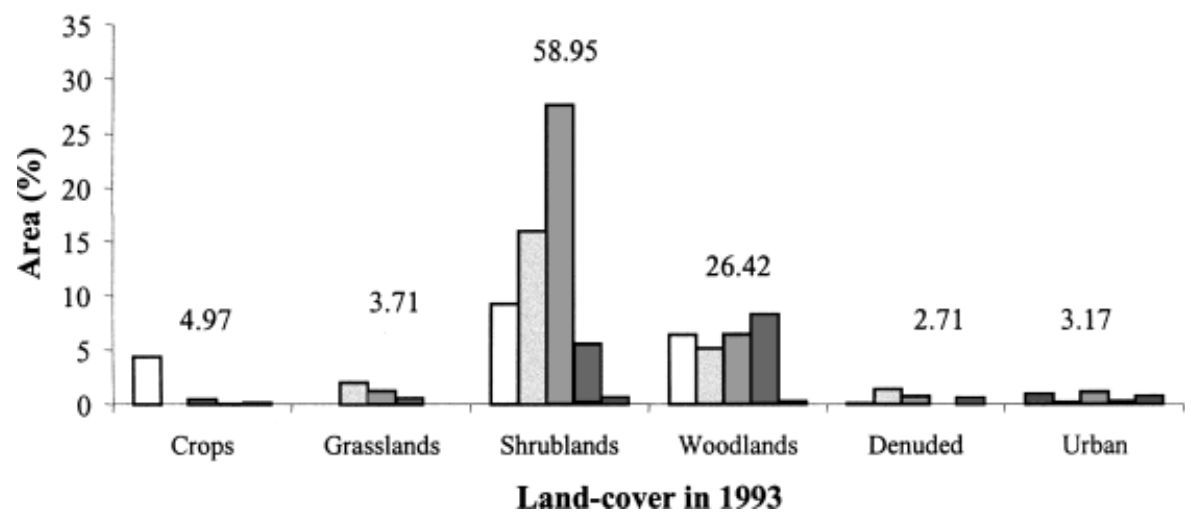

Fig. 1 Changes in land-cover from 1973 to 1993 and invasion of Opuntia maxima and O. stricta in Cap de Creus Natural Park, Catalonia (Spain) in relation to the land-cover in 1993 and land-cover change from 1973 to 1993. Numbers at the top of the bars represent the total percentage of the invaded area for a particular land-cover type in 1993. The area of urban land-cover in 1973 was not available.

O. stricta (Spearman correlation coefficient $r=0.09$, $P=0.59$ ). It is probable that Opuntia plants were introduced in croplands near urban areas. Indeed, $O$. maxima fruits are edible and it was probably introduced in small numbers for fruit consumption. Furthermore, Opuntia is present near urban areas where tourist resorts have proliferated in recent decades. Opuntia has been introduced as an ornamental and it is now 
Table 1 Percentage of initial land-cover (1973) that changed to new land-cover type by 1993 in Cap de Creus Natural Parc, Catalonia (Spain)

\begin{tabular}{lrllccrr}
\hline & Crops & Grasslands & Shrublands & Woodlands & Denuded & Urban & Total change* \\
\hline Crops & 29.01 & 0.43 & 53.74 & 9.15 & 0.87 & 6.80 & 70.99 \\
Grasslands & 3.41 & 4.27 & 68.86 & 14.83 & 6.88 & 1.75 & 95.73 \\
Shrublands & 1.87 & 1.37 & 71.91 & 16.38 & 7.44 & 1.04 & 28.09 \\
Woodlands & 2.48 & 1.14 & 71.43 & 19.47 & 3.85 & 1.64 & 80.53 \\
Denuded & 5.68 & 0.45 & 27.38 & 10.57 & 23.75 & 32.18 & 76.25 \\
\hline
\end{tabular}

*Total percentage of the 1973 area that has changed to another land-cover in this 20-year period.

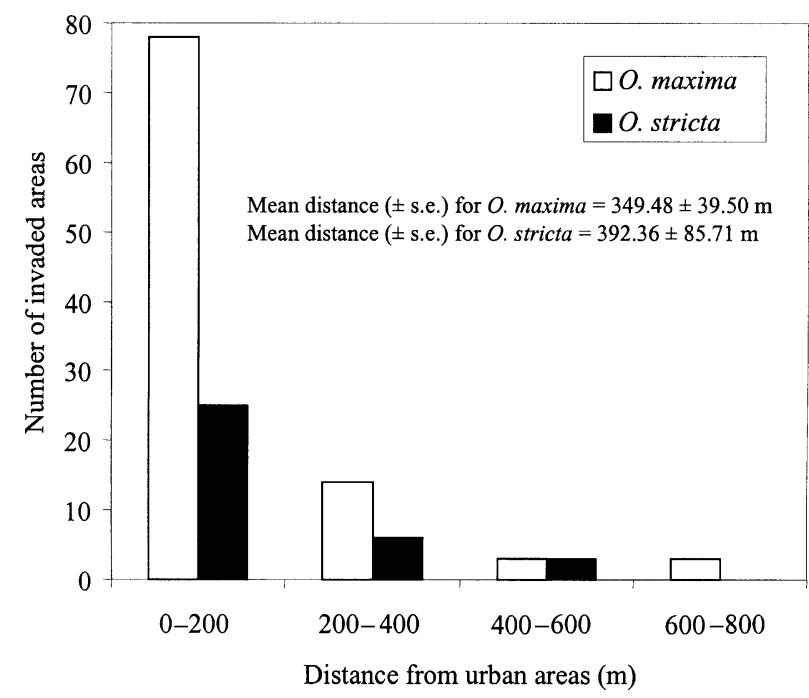

Fig. 2 Distribution of Opuntia maxima and O. stricta in relation to the distance from urban areas in Cap de Creus Natural Park, Catalonia (Spain).

invading as a result of anthropogenic dispersal via garden throw-outs (Hodkinson \& Thompson, 1994) or by deliberated planting around orchards colonizing and expanding its range into abandoned agricultural areas, preventing their restoration back to a Mediterranean shrubland free from alien species. Despite the long history of species interchange in the Mediterranean Basin, Mediterranean Basin shrublands are more resistant to invasions than other Mediterranean ecosystem types (Groves \& Di Castri, 1991). However, our study case represents an example in which the invasion by a single plant species poses an opportunity for a novel ecosystem to develop because the invader has functional traits qualitatively different from the other colonizing native species (Clark, 2000).

Overall, there is a general perception that changes in land-cover increase plant invasions because any change in the properties of an ecosystem will provide opportunities for new species to colonize and expand (Hobbs, 2000). Prior to this study, data from herbaria, floras and field surveys have found an association between the presence and abundance of key alien species and habitats that have experienced major modifications (e.g. roadsides and agro-ecosystems) compared to more natural habitats such as forests (Tyser \& Worley, 1992). However, these comparisons are between very contrasting habitats, where there is clear evidence that ecological differences are paramount. Moreover, compared to traditional grid-based systematic surveys, our approach is more refined because it allows testing if invasion within a habitat type is related to past changes in land-cover and that the invasionhabitat associations are not biased towards the most abundant habitats in the area of study. Furthermore, our method also has the advantage that it will offer the opportunity to assess accurately the persistence of the invaded area and the range of spread of these alien species in the future (Mack, 2000).

\section{Acknowledgements}

We thank J. Pausas and two anonymous referees for comments on an earlier version of the manuscript. The Departament de Medi Ambient de la Generalitat de Catalunya funded the elaboration of land-cover maps. Funding for conducting the field survey was provided by the Cap de Creus and Serra de la Verdera Natural Park, and the REN2000-0361/GLO project from the Ministerio de Ciencia y Tecnología to MV.

\section{References}

Barbera G, Carimi F, Inglese P (1992) Past and present role of the indian-fig prickly-pear Opuntia ficus-indica (L. Miller, Cactaceae) in the agriculture of Sicily. Economic Botany, 46, 10-20.

Bountin C, Jobin B (1998) Intensity of agricultural practices and effects on adjacent habitats. Ecological Applications, 8, 544-557.

Castroviejo S, Lainz M, López González G, Montserrat P, Muñoz-Garmendia F, Paiva J, Villar L (1990) Opuntia. In: Flora Ibérica II (eds Castroviejo S, Lainz M, López-González G, Montserrat P, Muñoz-Garmendia F, Paiva J, Villar L), pp. 6370. Servicio de Publicaciones del CSIC, Madrid.

Clark RP (2000) Global Life Systems: Populations, Food, and Disease in the Process of Globalization. Rowman and Littlefield, Lanham. 
Cody ML (1993) Do cholla cacti (Opuntia spp. subgenus Cylindropuntia) use or need nurse plants in the Mojave desert? Journal of Arid Environments, 24, 139-154.

Cortázar V, Nobel PS (1990) Worldwide environmental productivity indices and yield predictors for a CAM plant, Opuntia ficus-indica, including effects of doubled $\mathrm{CO}_{2}$ levels. Agricultural and Forest Metereology, 49, 261-279.

Cronk CB, Fuller JL (1995) Plant Invaders. Chapman \& Hall, London.

Debussche M, Lepart J, Dervieux A (1999) Mediterranean landscape changes: evidence from old postcards. Global Ecology and Biogeography Letters, 8, 3-16.

Ellenberg H (1989) Opuntia dillenii als problematischer Neophyt mi Nordjemen. Flora, 182, 3-12.

Folch R (1988) Natura, ús o abús? Llibre Blanc de la Gestió de la Natura als Països Catalans. Institució Catalana d'Història Natural, Ed. Barcino, Barcelona.

Franquesa T (1989) El paisatge vegetal de la Península del Cap de Creus (PhD Thesis,. Universitat de Barcelona, Barcelona.

Gersani M, Graham EA, Nobel PS (1993) Growth responses of individual roots of Opuntia ficus-indica to salinity. Plant, Cell and Environment, 16, 827-834.

Gimeno I, Vilà M (2002) Recruitment of two Opuntia species invading abandoned olive groves. Acta Oecologica, 23, 239-246.

Groves RH, Di Castri F (1991) Biogeography of Mediterranean Invasions. Cambridge University Press, Cambridge.

Hodkinson DJ, Thompson K (1994) Plant dispersal: the role of man. Journal of Applied Ecology, 34, 1484-1496.

Hobbs RJ (2000) Land-use changes and invasions. In: Invasive Species in a Changing World (eds Mooney HA, Hobbs RJ), pp. 31-54. Island Press, Washington, DC.

Inglese P, Barbera G, La Mantia T (1995) Research strategies for the improvement of cactus pear (Opuntia ficus-indica) fruit quality and production. Journal of Arid Environments, 29, 455-468.

Kowarik I (1990) Some responses of flora and vegetation to urbanization in central Europe. In: Urban Ecology (eds Sukopp H, Hejný S, Kowarik I), pp. 47-74. SPB Academic Publishing, The Hague.
Luo Y, Nobel S (1993) Growth characteristics of newly initiated cladodes of Opuntia ficus-indica as affected by shading, drought and elevated $\mathrm{CO}_{2}$. Physiologia Plantarum, 87, 467-474.

Mack (2000) Assessing the extent, status, and dynamism of plant invasions: current and emerging approaches. In: Invasive Species in a Changing World (eds Mooney HA, Hobbs RJ), pp. 141-170. Island Press, Washington, DC.

Pons X (2001) MiraMon. Geographic Information System and Remote Sensing Software. Centre de Recerca Ecològica i Aplicacions Forestals, Bellaterra, ISBN: 84-931323-5-7.

Pysek P (1998) Alien and native species in Central European urban floras: a quantitative comparison. Journal of Biogeography, 25, 155-163.

Sala OE, Chapin FS, Armesto JJ, Berlow E, Bloomfield J, Dirzo R, Huber-Sanwald E, Huenneke LF, Jackson RB, Kinzig A, Leemans R, Lodge DM, Mooney HA, Oesterheldand M, LeRoy N, Sykes MT, Walker BH, Walker M, Wall DH (2000) Global biodiversity scenarios for the year 2100. Science, 287, 1770-1774.

Thomson AG, Radford GL, Norris DA, Good JEG (1993) Factors affecting the distribution and spread of Rhododendron in North Wales. Journal of Environmental Management, 39, 199-212.

Tyser RW, Worley CA (1992) Alien flora in grasslands adjacent to road and trail corridors in Glacier National Park, Montana (USA). Conservation Biology, 6, 253-262.

Valiente-Banuet A, Ezcurra E (1991) Shade as a cause for the association between the cactus Neobuxbaumia tetetzo and the nurse plant Mimosa luisana in the Tehuacán Valley, Mexico. Journal of Ecology, 21, 324-331.

Vilà N (1996) Els sòls de la península del Cap de Creus.13-44. Annals del Institut d'Estudis Empordanesos, 29, 13-44.

Vilà M, Gimeno I (2001) Patterns of invasion of Opuntia sp. pl. in abandoned olive groves in Catalonia (Spain). In: Plant Invasions: Species Ecology and Ecosystems Management (eds Brundu G, Brock J, Camarda I, Child L, Wade M), pp. 169174. Backhuys Publishers, Leiden, The Netherlands.

Vitousek PM (1994) Beyond global warming: ecology and global change. Ecology, 75, 1861-1876. 